This article is distributed under the terms of the Creative Commons Attribution 3.0 PL (c) Copyright by Uniwersytet Warszawski Katedra Studiów Interkulturowych Europy

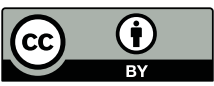

doi: 10.32612/uw.2543618X.2019.pp.77-87

Przegląd Środkowo-Wschodni, 4, 2019

ISSN 2543-618X elSSN 2545-1324

$\mathrm{Nr}$ art. 20190405

Data przesłania: 02.02 .2018

Data akceptacji: 23.05.2018

Ніна Стужынская

nina.stuzh@wp.pl

ORCiD: 0000-0002-6184-1650

\title{
Гісторыя Атамана Грача
}

\section{Historia Atamana Hracza}

Artykuł opowiada o losach uczestnika antybolszewickiego ruchu partyzanckiego Włodzimierza Ksieniewicza (pseudonim Ataman Hracz). Jest to postać mało dotąd znana i nieobecna w historiografii. W 1924 roku Ataman Hracz przekroczył granicę polsko-sowiecką i przedostał się na Białoruś Sowiecką, gdzie wkrótce został aresztowany i skazany. Akta dotyczące śledztwa są przechowywane w Archiwum Komitetu Bezpieczeństwa Państwowego Republiki Białoruś. Na podstawie akt sądowych autorka odtwarza kolejne etapy działalności partyzanta. Tragiczne losy tego działacza zostały ukazane na tle wydarzeń politycznych, które rozgrywały się wówczas w regionie.

Słowa kluczowe: walka antybolszewicka, partyzantka, Białoruś, niepodległość

Кіраўнік галоўнага штаба Беларускай сялянскай партыі «Зялёны дуб» (ЗД) Уладзімір Францавіч Ксяневіч падчас дыверсійнай і разведвальнай дзейнасці карыстаўся партыйным псеўданімам Грач і зрэдку, пасля 1922 года, Гансоўскі.

Найбагацейшая паводле матэрыялаў крыніца па гісторыі ЗД справа У. Ксяневіча, што датуецца кастрычнікам 1924 - чэрвенем 1927 года і захоўваецца ў Цэнтральны архіве Камітэта дзяржаўнай бяспекі Рэспублікі Беларусь (ЦА КДБ РБ). Гэта пратаколы допытаў, уласнаручныя паказанні, агентурныя данясенні, перапіска асоб, 
звязаных са справай, фотаздымкі, якія датуюцца 1922-1925 гадамі. Крымінальная справа была заведзена 12 чэрвеня 1925 года і за два тыдні падрыхтавана да суда. 3 кастрычніка 1924 года У. Ксяневіч знаходзіўся, можна меркаваць, у падвалах ДПУ БССР. У папцы, падрыхтаванай да суда, былі сабраны матэрыялы пра антысавецкую тэрарыстычную дзейнасць Грача 3 моманту ўступлення ў ЗБ (восень 1920 года) і да яго пераходу ў Савецкую Беларусь у кастрычніку 1924 года. Прысутнічаюць і дакументы асабістага характару лісты да жонкі. На падставе гэтай справы Грача былі падрыхтаваны першыя публікацыі па гісторыі ЗД ${ }^{1}$.

3 дапамогай інтэрнэта знайшоўся ўнук У. Ксяневіча - Юрый Каюкоў, які жыве ў Екацерынбургу (Расія).

Такім чынам, да першай часткі жыццяпісу атамана, які склалі ў Менску чэкісты Пятроў, Дамберг, Генкін і Апанскі, далучылася другая - $з$ Далёкага Усходу. Ю. Каюкоў даслаў копію следчай справы № 10613 па абвінавачванні У. Ф. Ксяневіча па арт. 58-6 КК РСФСР (захоўваецца ў асабістым архіве аўтара). Гэта быў вынік плённай працы супрацоўнікаў Балейскага раённага аддзела УНКУС па Чыцінскай вобласці. Такім чынам, знайшлася крыніца 3 адлюстраваннем фінальнай часткі жыццёвага шляху кіраўніка галоўнага штаба ЗД.

Чыцінскія матэрыялы маюць крайнія даты: 25 студзеня 1938 i 4 ліпеня 1939 года. У іх змешчаны пратаколы допытаў Грача, яго жонкі Ксеніі Максімаўны, прыгавор, апеляцыя і адмова ў памілаванні, а таксама даведка аб выкананні рашэння суда.

Абедзве справы заканчваюцца аднолькавым прыгаворам: да вышэйшай меры пакарання - расстрэлу. Але ў 1925 годзе Грач змог яго пазбегнуць, адклаўшы непазбежнае на 14 гадоў і заплаціўшы вельмі дарагую цану за памілаванне. Грач пагадзіўся на супрацоўніцтва $з$ АДПУ БССР, яго ўратаваў І. Апанскі, які выкарыстоўваў тактыку перавярбоўкі палітычных апанентаў, якую практыкавала

${ }^{1}$ Н. Стужынская, Зялёнадубизы і іншыя, «Літаратура і мастацтва» 1994, 16 снежня; Idem, Трагедыя зялёнадубиаў, «Беларускі гістарычны часопіс» 1996, № 1. 
кіраўніцтва АДПУ ў Маскве, і выступаў супраць іх знішчэння без спробы з выгадай выкарыстаць чалавека, які, трапіўшы ў чэкісцкую пастку, не меў альтэрнатывы.

Другая частка крыніц - публікацыі ў савецкай прэсе. Намаганнямі тагачасных партыйных ідэолагаў і журналістаў ход судовага разбіральніцтва меў характар гучнага і шматлюднага шоў. Паралельна разглядаліся справы польскіх шпіёнаў і ўдзельнікаў нападу на мястэчка Койданава. На некаторых пасяджэннях Грач выступаў як сведка. У гэтай якасці ён выступаў па прапанове пракурора А. Вышынскага, будучай «зоркі» расстрэльных працэсаў у $\mathrm{CCCP}^{2}$. Гісторыя Грача была тэмай шэрагу публікацый у афіцыйных выданнях БССР «Звезда» і «Савецкая Беларусь» на працягу 19251926 гадоў.

У 2017 годзе праўнукі атамана даслалі копію працоўнай кніжкі У. Ксяневіча (захоўваецца ў асабістым архіве аўтара), якая сведчыць пра пакуты сям'і на чужыне, праблемы з працаўладкаваннем і жыллём. Дыялог з нашчадкамі атамана Грача працягваецца. Адгукнулася праўнучка з ЗША, доктар Вольга Джэймс, якая дадала факты $з$ жыцця прапрабабкі, жонкі У. Ксяневіча - Ксеніі Максімаўны, яе дачок.

Дакументы 1924-1925 гадоў сведчаць пра трагічную памылку атамана Грача - пераход на савецкі бок, адлюстроўваюць сумную карціну наступстваў гэтага кроку, адносіны са следчымі ДПУ і спробы захаваць жыццё. 3 Грачом працавалі кіраўнікі ДПУ БССР.

Следчыя матэрыялы маюць подпісы Афрыкана Пятрова, чэкіста, які меў багаты вопыт распрацоўкі спраў зялёнадубаўцаў і іншых беларускіх палітыкаў. Усевалад Фальскі, першы камісар па замежных справах Сацыялістычнай Савецкай Рэспублікі Беларусі, пасля допытаў следчага Пятрова спрабаваў скончыць жыццё самагубствам³.

2 «Звезда» 1925, 25 февраля.

${ }^{3}$ Н. Стужинская, Роли Всеволода Фальского: судьба наркома иностранных дел в первом советском правительстве Беларуси [online], https://m.nn.by/ru/ articles/169974/ [доступ: 16.04.2018]. 
Адзін 3 прыхільнікаў Б. Савінкава, атаман з Ігуменскага павета Уладзімір Гаркавенка-Багнавец скардзіўся на следчага ў вышэйшыя інстанцыі: «Ён [Пятроў. - H. C.] ужо з раніцы не можа без нянавісці глядзець на падследных і іх сваякоў, пакутуючы ад жадання апахмяліцца» ${ }^{4}$. Зялёнадубаўцы адзначалі неаб’ектыўнасць і нічым не апраўданую жорсткасць следчага.

Аднак на старонках літаратурных твораў пра чэкістаў і «бандытаў» паўстаюць зусім іншыя вобразы. Ілья Барысаў, які пісаў пра «падрыўную дзейнасць антысавецкай нацыялістычнай арганізацыі „Зялёны дуб”», апісвае Пятрова як «стрыманага інтэлігентнага» чалавека, а Генкіна як імпульсіўнага, але разумнага (яму была перададзена крымінальная справа Грача) ${ }^{5}$.

Дакументы 1924-1927 гадоў захавалі інфармацыю пра розныя бакі існавання і дзейнасці ЗБ. У іх змешчаны звесткі пра добры тузін імён тагачасных беларускіх, польскіх, расійскіх палітыкаў, пра ўзаемаадносіны паміж імі. Чэкісты крок за крокам выцягвалі з У. Ксяневіча падрабязнасці пра яго сувязі з польскай разведкай, адносіны 3 афіцэрамі $d w o ́ j k i$ : Блонскім, Зацвіліхоўскім, Маерам і іншымі.

На падставе згаданых крыніц ёсць магчымасць скласці даволі падрабязную біяграфію У. Ксяневіча.

Крыніцы багатыя таксама на мянушкі і партыйныя псеўданімы лідараў антысавецкага партызанскага руху. Гэта стварае для даследчыка дадатковыя цяжкасці ў справе ідэнтыфікацыі асоб. 3 ЗБ каардынавалі сваю дзейнасць атаманы Мяфодзій і Іван Караткевічы, Цімох Хведашчэня, Георгій Моніч і іншыя.

База ЗД першапачаткова размяшчалася ў Лунінцы. Гэты гарадок са старонак справы Грача выглядае цэнтрам антысавецкага партызанскага руху, лагерам падрыхтоўкі дыверсійных акцый. У раёне вакзала знаходзіўся бронецягнік «Балаховец», на якім служыў

${ }^{4}$ Цэнтральны архіў Камітэта дзяржаўнай бяспекі Рэспублікі Беларусь (ЦА КДБ РБ), крымінальная справа У. Гаркавенкі-Багнаўца.

${ }^{5}$ І. Барысаў, Крах «Зялёнага дуба», «Звязда» 1991, 15 сакавіка. 
У. Ксяневіч да пераходу ў ЗД. Пасля няўдалага Палескага паходу генерала С. Булак-Балаховіча, падчас інтэрніравання яго арміі зялёнадубаўцы здымалі з цягніка зброю і выбуховыя матэрыялы і перадавалі слуцкім паўстанцам. Грач эмацыянальна і з падрабязнасцямі намаляваў карціну «рабунку» цягніка. Польскі бок, заплюшчваючы вочы на «крадзеж» зброі, такім чынам дапамагаў паўстанцам, фармальна не парушаючы Рыжскага дагавора.

Кавярня Маліноўскага на вакзале Лунінца была месцам, дзе пасля баявых паходаў адпачывала моладзь. Партызаны М. Караткевіча парушалі спакой і сон мясцовых жыхароў, спяваючы баявы марш «Адвеку мы спалі». У рэстаране высвятлялі адносіны зялёнадубаўцы і савінкаўцы. Выпадковыя саюзнікі нярэдка вырашалі пытанні з дапамогаю зброі. Лунінец быў «цесны» для расійскіх баевікоў і беларускіх партызан. Грач апісвае выпадак, як аднойчы кіраўнік ЗД атаман Дзяргач цяжка параніў савінкаўскага палкоўніка Вайцяхоўскага ля дзвярэй кавярні. Але канфлікт быў не патрэбен палітыкам, і справу спынілі'.

Вельмі красамоўна дакументы сведчаць пра фарміраванне беларускай ідэнтычнасці У. Ксяневіча, які паходзіў з польскай сям'i, але стаў перакананым беларусам. Як гэта адбывалася, якія фактары паўплывалі на свядомасць маладога афіцэра, чаму ён зрабіў выбар на карысць беларускай ідэі? 3 заканчэннем Першай сусветнай вайны і развалам царскай арміі маладыя вайскоўцы беларускага паходжання шукалі апірышча на бацькаўшчыне. У. Ксяневіч вярнуўся дамоў з Румынскага фронту, дзе знаходзілася многа беларусаў. У акупіраваным палякамі Менску У. Ксяневіч даведаўся аб дзейнасці Беларускай вайсковай камісіі, якая камплектавала афіцэрскі рэзерв. «Я, як беларус, з чыста нацыяналістычных пачуццяў добраахвотна ўступіў у БВК», - патлумачыў следчаму ДПУ матывацыю свайго выбару У. Ксяневіч 7 . Але ўжо праз месяц «наваспечаны»

\footnotetext{
${ }^{6}$ ЦА КДБ РБ, крымінальная справа У. Ксяневіча.

${ }^{7}$ Ibidem.
} 
беларускі афіцэр зразумеў, што дзейнасць БВК не прынясе плёну. Паўтара месяца У. Ксяневіч служыў у сапёрнай роце № 219 Войска Польскага. Але назіраючы, як польскія салдаты рабавалі беларускае насельніцтва, адчуў сябе пакрыўджаным беларусам. Крыўда вырасла ў памерах, калі ён стаў сведкам, як афіцэр, сквапны да дабра беларускага селяніна, пакараў галоднага жаўнера за спробу злавіць курыцу на польскай тэрыторыі. «Браць можна толькі ў беларусаў», - патлумачыў афіцэр. Пра гэты выпадак, які падштурхнуў пакінуць Войска Польскае, нягледзячы на тое, што там служыў бацька, Грач расказаў на сваім першым судовым працэсе ў Менску8.

Незважаючы на пераважна варожую аўдыторыю, на судзе У. Ксяневіч пранікнёна ўспамінаў, як аднойчы, чытаючы беларускі каляндар, адчуў, што беларушчына - гэта яго мова, а Беларусь яго зямля, краіна. Натоўп, які чэрвеньскім днём 1924 года набіўся у залу суда менскага Дома культуры, каб паглядзець на «польскага шпіёна», наўрад ці зразумеў пафас прамовы падсуднага: «Калі вучыўся ў Варшаве, мяне прымалі за рускага, у Разані супрацоўнікі лічылі палякам [там У. Ксяневіч у 1919 годзе працаваў у ваенным камісарыяце. - H. С.], але ні тым, ні другім я не быў»9. У. Ксяневіч спадзяваўся, што адданасць беларускай ідэі яго ўратуе. Нацыянальная рыторыка, якую пачалі выкарыстоўваць савецкія ўлады, наяўнасць наверсе палітычнай піраміды ССРБ нацыянал-камуністаў шмат каго $з$ яго акружэння дэзарыентавала.

Грач ва ўласнаручных паказаннях напісаў: «Я - нацыяналіст-беларус». Зялёнадубавец атаман Міхаіл Крук, які перайшоў на савецкі бок у 1922 годзе, стараўся ўсіх былых паплечнікаў на допытах у ДПУ выставіць «панскімі паслугачамі», аднак пра Грача сказаў: «Не церпіць нічога польскага, марыць аб незалежнай Беларусі ${ }^{10}$.

\footnotetext{
8 «Звезда» 1925, 27, 29 июня.

9 ЦА КДБ РБ, крымінальная справа М. Крука.

${ }^{10}$ I. Барысаў, op. cit.
} 
У. Ксяневіч памыліўся ў сваіх разліках на аднадумцаў сярод беларускіх бальшавікоў.

Атаман Грач шчыра жадаў палепшыць жыццё простых людзей, таму партыя Адамовічаў прывабіла яго сваёй назвай «сялянская». «Мяне заўсёды цягнула да майго цёмнага народа», - пісаў вязень у паказаннях у ДПУ. Ён лічыў, што «толькі школа на роднай мове выратуе нацыю» ${ }^{11}$. Паказальна, што У. Ксяневіч не адмовіўся ад сваіх «нацыяналістычных» поглядаў і падчас допытаў забайкальскімі чэкістамі ў 1938 годзе.

Крыніцы сведчаць, што ў гродзенскай турме, дзе У. Ксяневіч адсядзеў пяць месяцаў, ён глыбока вывучаў Евангелле. У маі 1923 года прыняў хрышчэнне ад Лукаша Дзекуць-Малея, вядомага беларускага пастыра евангельскай царквы хрысціян-баптыстаў, які паходзіў са Слонімшчыны і вучыўся ў Слоніме - родным горадзе У. Ксяневіча. Будучы духоўны настаўнік быў на шэсць год старэйшы за У. Ксяневіча, але, магчыма, іх знаёмства пачалося з дзяцінства. Можна меркаваць, што супрацоўніцтва беларускіх патрыётаў наладзілася ў Гродне. Атаман Грач паведамляў, што ў 1923 годзе Л. Дзекуць-Малей разгарнуў працу ў Брэсце. Вернікі знайшлі памяшканне для сходаў - падвал пад адной з гасцініц (цяпер гэта будынак на вул.Савецкай, 13) і заснавалі там культурна-асветную арганізацыю «Беларуская хатка» ${ }^{12}$.

Л. Дзекуць-Малей мог паўплываць на істотныя змены ў свядомасці былога баевіка. Як успамінаў У. Ксяневіч на допыце ў ДПУ, «стары Адамовіч, жартуючы, пачаў называць мяне святым. Я кінуў курыць, выпіваць». Далейшыя духоўныя пошукі прывялі У. Ксяневіча ў Варшаўскую біблейскую школу, дзе ён вучыўся, вёў гаспадарку і выкладаў арыфметыку. Большасць слухачоў школы была малапісьменная. У лісце У. Ксяневіча да жонкі адчуваецца ўзнёсласць яго рэлігійнага настрою. У. Ксяневіч прымаў удзел у з'ездах

\footnotetext{
11 «Звезда» 1924, 5 сентября.

12 Ibidem.
} 
баптыстаў. Якія абставіны спынілі яго на гэтым шляху, невядома, але, як ён сам засведчыў, у баптызме задавальнення не знайшоў. У анкетах пра веравызнанне пісаў «евангеліст» ${ }^{13}$.

3 мэтай пранікнення ў антысавецкія арганізацыі за межамі СССР савецкімі спецслужбамі была распрацавана аперацыя «Трэст». Сцэнай для яе ажыццяўлення стала тэрыторыя БССР. Ствараліся арганізацыі-легенды, якія імітавалі вядомыя ў эміграцыі структуры. Так узніклі Манархічная арганізацыя цэнтральнай Расіi, Ліберальныя дэмакраты (ЛД). Праз гэтыя структуры чэкісты на працягу шасці гадоў шукалі кантакты з антысавецкімі цэнтрамі за мяжой i, пранікаючы ў ix, затым іх ліквідавалі. Актыўнымі ўдзельнікамі аперацыі «Трэст» былі чэкісты ССРБ І. Апанскі, П. Мядзведзь, Н. Эйтынгон і іншыя. 3 РСФСР былі накіраваны Віктар Банга, Станіслаў Глінскі, Ян Крыкман і іншыя.

Выдаючы сябе за члена ЛД С. Глінскі, напрыклад, інспектаваў паўстанцкія атрады. Давераная асоба Б. Савінкава, свой сярод зялёнадубаўцаў, ён адыграў злавесную ролю арганізатара ix гібелі. С. Глінскі, адзін з актыўных выканаўцаў аперацыі «Сіндыкат-2», персанальна адказваў за пераход Б. Савінкава і яго паплечнікаў на давераным яму ўчастку дзяржаўнай граніцы ў СССР. У мэтах дасягнення паспяховага фіналу ігры з Б. Савінкавым 16 чэрвеня 1922 года С. Глінскі быў прызначаны начальнікам Заслаўскага пагранічнага асобага аддзялення ДПУ. Тут жа працаваў заканспіраваны чэкіст Батаў (Крыкман). Яны забяспечвалі «калідор» для пераходу Б. Савінкава ${ }^{14}$. Глінскі «дапамог» перайсці граніцу і У. Ксяневічу. Пад якім прозвішчам Грач ведаў С. Глінскага застаецца таямнцай, але, безумоўна, яны былі добра знаёмыя.

У. Ксяневіч падчас першага арышту ўтаіў, што меў у Менску яўку, якую атрымаў у Вільні ад Радаслава Астроўскага, - у П. Мядзведя, старшыні ДПУ Беларусі. Прызнанне У. Ксяневіча, зробленае ў 1938

13 Успаміны Соф’і Апанасаўны Грыц, навучэнкі Віленскай беларускай гімназіі ў 1920-я гады, запісаныя аўтарам у 1998 годзе, калі С. Грыц было 94 гады.

${ }^{14}$ I. Барысаў, op. cit. 
годзе, ужо не ўплывала на лёс П. Мядзведзя, які быў растраляны ў лістападзе 1937 года. Піліп Дзям'янавіч Мядзведзь быў адной 3 ключавых фігур аперацыі «Сіндыкат-2». Мяркуючы па ўсім, Атаман Грач глыбока ўлез у павуцінне «Трэста». Кіраўніцтва ЗД само часцяком удала блефавала. Але ў выпадку з У. Ксяневічам шмат людзей, свядома ці не, удзельнічала ў падрыхтаваных чэкісцкімі вынаходнікамі падзеях. Угаворвалі, падштурхоўвалі, стваралі праўдападобную легенду, накіроўвалі і суправаджалі... у пастку.

Б. Савінкаў, хаўруснік зялёнадубаўцаў і знаёмы У. Ксяневіча, быў арыштаваны ў жніўні 1924 года. Смяротнае пакаранне яму замянілі на дзесяцігадовы турэмны тэрмін. Пакаянныя прамовы Б. Савінкава мелі каласальны рэзананс: «3 беларускіх ускраін Польшчы паведамляецца, што сярод прыхільнікаў Савінкава пануе поўная разгубленасць. Можна меркаваць, што частка з іх пойдзе па яго слядах і пераменіць свае адносіны да савецкай улады» ${ }^{15}$.

Ігра працягвалася. Памілаванне Б. Савінкава было выдатным палітычным крокам. Адтэрміноўка пакарання спарадзіла ў часткі стомленых баевікоў хісткія надзеі на паразуменне з бальшавікамі. Атаман Грач, які паўтарыў шлях Б. Савінкава літаральна па свежых слядах, мог трапіць у палон такіх ілюзій.

Увогуле, меркаванняў пра прычыны пераходу Грача на савецкі бок шмат. Ціск палітычных фактараў на яго лёс быў каласальны. Знаходжанне сям'і на савецкай тэрыторыі рабіла яго заложнікам вымушаных небяспечных крокаў. Савецкія спецслужбы намагаліся пераканаць антысавецкія «элементы» ў адсутнасці перспектыў барацьбы, паспяхова карыстаючыся негатыўным уплывам на людзей розных жыццёвых фактараў. Незапатрабаванасць прафесіяналаў, палітычны ціск улад, якія далі прытулак, а самае галоўнае - страта бацькаўшчыны, сям’і, пра што сведчаць крыніцы, - рабілі з эмігранцкіх дзеячаў лёгкую здабычу для чэкістаў - спрактыкаваных «паляўнічых».

15 «Звезда» 1924, 5 сентября. 
Пасля заключэння Рыжскага дагавора дзейнасць антысавецкай узброенай апазіцыі знаходзілася пад пільнай увагай як савецкіх, так і польскіх улад. Для абедзвюх прыхільнікі незалежнасці Беларусі былі перашкодай у іх імперыялістычных планах. Увосень 1921 года амаль усе лідары беларускага партызанскага руху ў Заходняй Беларусі былі арыштаваны і размеркаваны па польскіх турмах і лагерах, дзе знаходзіліся дастаткова працяглы час. На думку польскіх палітыкаў, факт наяўнасці вайсковых баз і баявой дзейнасці, якая практычна не магла быць заканспіравана цалкам, пагражала канфліктам з Савецкай Расіяй.

Відавочным было глыбокае расчараванне беларускіх палітыкаў вынікамі супрацоўніцтва 3 польскімі ўладамі. Позіркі пакрыўджаных накіроўваліся ў бок імаверных саюзнікаў: Германіі, Літвы, СССР. Беларускія левыя палітыкі ўсё больш упэўнена заяўлялі, што «па той бок граніцы савецкі ўрад будуе новы дом для беларускага народа» ${ }^{16}$. Савецкі Менск не шкадаваў грошай на падтрымку лаяльных да камуністаў палітычных партый і сродкаў масавай інфармацыі ў Заходняй Беларусі. Яны сеялі ілюзіі «беларускага адраджэння» ў БССР.

Асяродкам выхавання левых, радыкальных «чырвоных» поглядаў стала Віленская беларуская гімназія на чале 3 дырэктарам Радаславам Астроўскім. Не было вялікім сакрэтам, што гэта навучальная ўстанова атрымлівала грашовую дапамогу з Менска ${ }^{17}$. Менавіта Р. Астроўскі выступіў гарантам бяспекі У. Ксяневіча пры падрыхтоўцы і ажыццяўленні аперацыі «Пералёт» па яго пераходзе ў БССР. Дзяргач пераконваў, што дзеячы ў Менску і група Астроўскага ў Вільні - гэта адна «кампанія» («Трэст»?). Падчас асабістай сустрэчы напярадэдні адпраўкі ў БССР Дзяргач даў Грачу адрасы кантактных асоб: У. Ігнатоўскага, П. Мядзведзя і іншых, параіў У. Ксяневічу, якім маршрутам лепш трапіць у Менск. Халодным душам для У. Ксяневіча сталі словы У. Ігнатоўскага, якога

\footnotetext{
${ }^{16}$ Ibidem.

17 Успаміны С. А. Грыц.
} 
выклікалі ў ДПУ ў якасці сведкі, што «справа пахне нейкай правакаuъьяй». Але потым У. Ігнатоўскі ўспомніў пра шчыльныя адносіны Р. Астроўскага з віленскімі камуністамі і палічыў, што менавіта яны маглі садзейнічаць у справе У. Ксяневіча. Паказанні У. Ксяневіча 1938 года пераканаўча сведчаць пра дачыненне Р. Астроўскага да аперацыі «Трэст». Лінія паводзін I. Апанскага ў дачыненні да Грача, прапанова захаваць жыццё ў абмен на супрацоўніцтва таксама сведчаць аб рэалізацыі загадзя спланаванай аперацыі.

Архіўныя крыніцы

Цэнтральны архіў Камітэта дзяржаўнай бяспекі Рэспублікі Беларусь, крымінальныя справы У. Гаркавенкі-Багнаўца, У. Ксяневіча, М. Крука.

\section{Літаратура}

Барысаў I., Крах «Зялёнага дуба», «Звязда» 1991, 15 сакавіка. «Звезда» 1924, 5 сентября; 1925, 25 февраля, 27, 29 июня.

Стужинская Н., Роли Всеволода Фальского: судьба наркома иностранных дел в первом советском правительстве Беларуси [online], https://m.nn.by/ ru/articles/169974/ [доступ: 16.04.2018].

Стужынская Н., Зялёнадубиы і іншыя, «Літаратура і мастацтва» 1994, 16 снежня. Стужынская Н., Трагедыя зялёнадубиаў, «Беларускі гістарычны часопіс» 1996, № 1.

\section{History of the Ataman Hrač}

The article tells the story of a participant in the anti-Bolshevik guerrilla movement of Uladzimir Ksianievič (pseudonym Ataman Hrač). He is a man not known and known until recently in historiography. In 1924, Ataman Hrač crossed the Polish-Soviet border and made it to Soviet Belarus, where he was soon arrested and convicted. Files regarding the investigation are kept in the Archive of the State Security Committee of the Republic of Belarus. Based on court files, the author of a given publication reproduces the subsequent stages of the fate of the guerrilla. The tragic fate of this activist was shown against the background of political events that took place in the region at that time.

Keywords: anti-Bolshevik struggle, partisans, Belarus, independence 